\title{
STRATEGY PATTERNS AND CORPORATE COMPETITIVE ADVANTAGE IN HYPERCOMPETITION
}

Action aggressiveness is considered as a firm response to the phenomenon of temporary advantage. Firms able to respond quickly to market demands strengthen their market power and generate advantages; but those that can be even faster, will generate even greater market power and advantage over its competitors. However, there is no guarantee that competitive advantage achieved today will remain unchanged in the long run. The focus is on being prepared to take an action, i.e. the extent to which the firm is willing to participate with competitors and act quickly in the involvement and participation. The dynamics of top management is a very important component of the ability of the firm competitive behavior. The top management team is the kingpin that coordinates and mobilizes organizational resources and efforts for firms' aggressive competitive engagement. The assumption of being more aggressive at the market and collaborative with competitors is the integration of top management of the firm that depends primarily on compatible traits and members' communication skills. With a special focus on top management teams, this paper explores the extent to which firms' certain strategic behavior in hypercompetitive industry can be related to gaining temporary competitive advantage, measured through improving its firm performance. The central goal of this research is to theoretically and empirically define and examine firms' strategic behavior in hypercompetition through defining new taxonomy of strategy patterns, i.e. firm specific strategic behavior that provides and raises the probability of gaining the competi-

* M. Daraboš Longin, Ph. D., Assistant Professor, Faculty of Economics and Business, University of Zagreb (E-mail: mdarabos@efzg.hr).

The paper was received on February 15th, 2018. It was accepted for publication on March 19th, 2018. 
tive advantage in hypercompetitive industries. An important contribution of this research is also reflected in the development of the model that analyze the influence of specific characteristics of top management team (TMT) on pattern firm uses, as well as the relationship between firms' market position on specific strategic behavior.

Key words: aggressiveness, competitive advantage, firm performance, hypercompetition, top management team (TMT), strategy pattern

\section{Introduction}

Competitive dynamics is a phenomenon that is becoming more evident in many industries, even in those that were considered relatively stable until recently. There has been an alternation in the competitive conditions in various industries, i.e. hypercompetitive shift, visible through a sudden increase in competitive activity, greater variability in the profitability of the industry, as well as in noticeable changes in market shares (Ferrier, Smith and Grimm, 1999). Firms' advantages are becoming more temporary in nature, due to the various disturbances occurring in the business environment and given the fact that competitor activity is becoming more frequent and firms must continuously develop and find new strengths and constantly monitor market changes and competitor moves (McNamara, Vaaler and Devers, 2003; Wiggins and Ruefli, 2005; Thomas and D'Aveni, 2004). The goal of this paper is to theoretically and empirically indicate the relationship between firms' strategic pattern - certain behavior and gaining competitive advantage in hypercompetitive industries. Although a growing number of empirical studies dealing with the issue of achieving and maintaining competitive advantage in an era of hypercompetition could be seen, they were primarily focused towards analyzing competitive dynamics and its impact on the financial performance of the firms. However, there was no conceptual framework of strategic behavior proposed, or a strategy that businesses would use to achieve competitive advantage in terms of hypercompetition. So, the paper's intention is to define and examine firms' strategic behavior in hypercompetition, not only through defining taxonomy of particular strategy patterns but also through analyzing the influence of specific characteristics of top management team (TMT) on patterns firm uses, as well as relationship between firms' market position on specific strategic behavior (Darabos, Prester, Tipurić, 2015; Darabos, 2014b). 


\section{Theoretical framework}

Recent studies indicate that a sustainable competitive advantage is becoming rare, while its duration decreases (Wiggins and Ruefli, 2002) as a result of dynamic interaction between competitors (Sirmon, et al. 2010). The environment in which advantages are created fast and eroded even faster is called hypercompetiton (D'Aveni, 1994). It is characterized by intense competition and rapid moves, where firms must constantly develop advantages and destroy, or endanger competitors' advantages. The emergence of hypercompetition is result of increasingly rapid and intense technological changes caused by technological advance and innovations, as well as distribution and availability of firm's resources.

Hypercompetition and competitive dynamics are essential for understanding how dynamics and competitive intensity of business environment lead to temporary competitive advantage. Theoretical approach of competitive dynamics shows that relationship between firm's strategy and firm performance primarily depends on firm strategic behavior, but also on competitors' behavior and interactions between them. (Grimm, Lee, and Smith, 2006). Hypercompetition is focused and assumes specific actions initiated by the firm, as well as competitors' responses on those actions.

Recent studies were exploring mostly the new conditions brought by hypercompetiton and the fact that maintaining competitive advantage is becoming increasingly difficult, almost impossible. However, very few examined how firms should react, make decisions and progress in such environment. Firm strategic behavior in the dynamic environment requires active presence on the market, i.e. aggressiveness in undertaking actions. Thereby, Ferrier defines firms' competitive attack through numerous competitive actions initiated by the firm, which are most often disrupted by responses of one or more competitors (Ferrier, 2001). Furthermore, undertaking strategic actions can be seen as an externally oriented, specific and visible competitive move initiated by the firm willing to improve its own competitive position (Ferrier, Smith and Grimm, 1999; Young, Smith, and Grimm, 1996; Smith et. al., 1991). In his longitudinal study, Chen shows that the most important factors that influence firm strategic behavior include context recognition and motivation and ability to undertake actions (Chen, 1996). Firm's abilities should encompass organizational preconditions for strengthening its competitive potential (Ferrier, 2001), as well as individual assumptions of firm's strategic decision makers (Bazerman and Schoorman, 1983; Goodstein, and Escalas, 1994). Ferrier shows the faster the decision making process related to action implementation is, the increase in the market share of the firm will be more visible (Ferrier, 2001; Smith, Ferrier and Grimm, 2001).

TMT is a key factor in the whole process, by making all decisions about directions of firm's development, identifying business opportunities and coordinat- 
ing activities and mobilizing the resources of the firm in order to make the most of identified opportunities. Previously stated will result in readiness for aggressive competitive engagement (Hambrick, Cho and Chen, 1996; Baron, 2007; Ozgen and Baron, 2007). TMT members characteristics, such as knowledge, skills they poses, their experience and reputation; which all together create human capital; bring in valuable resources for the firm. Competence and expertise of TMT refers to necessary knowledge, functional and specific, essential to understand business and governance processes. Smith et. al. show that a particularly important role in the firm's competitive behavior in the hypercompetitive industries play socialbehavioral integration of the TMT, i.e. the degree to which members collaborate and work with each other (Smith et. al., 1994). Cohesiveness, on the other hand, refers to the degree of "attraction" among TMT members, as well as the degree of work motivation (Summers, Coffelt, and Horton, 1988). The higher level of cohesion can result in stronger influence of TMT on effort members make in the performance of their duties, since groups characterized by a high degree of cohesiveness can influence its members behavior to a greater extent. Furthermore, in the hypercompetitive industries entrepreneurial spirit is very important characteristic of TMT behavior, considering that actions' frequency and attributes depend on entrepreneurial spirit of manager. That is expressed through proactivity measures, innovation measures and risk aversion (Bruining, and Wright, 2002).

Also, it is the fact that maintaining leading market position in the long term in the dynamic industry is very difficult, representing the motive for examination whether there is a connection between firm's current position in the industry and strategic pattern firm follows, i.e. to examine how firm's current position in the industry determine firm strategic behavior.

\section{Description of the proposed model}

Existing researches related to achieving competitive advantage in the hypercompetitive conditions offer different approaches regarding to analysis and research of mentioned field. However, a conceptual framework of strategic behavior, i.e. possible strategies firms may follow in order to achieve competitive advantage in the hypercompetiton, has not been proposed yet. Therefore, the research problem of this paper stems from an insufficient understanding of key determinants of the firm strategic behavior and offers a new research approach to the analysis of achieving competitive advantage in the hypercompetitive industries with the practical application. Given approach encompass defined and structured behaviors of firms that are framed in the newly formed strategic taxonomy of strategy patterns, supported with an empirical study of the strategic behavior of firms in Croatia. 
Daraboš (2014) developed the model that explains relationship between strategic patterns and competitive advantage in the hypercompetition (Fig 2). Previous studies have partially examined some characteristics of firm strategic actions and their influence on firm performance (Ferrier, 2001; Ferrier, 1999; Chen, Smith, Grimm, 1992; Chen, MacMillan, 1992; Smith, Grimm, Gannon, 1992). Furthermore, the model provides a holistic view of link between individual characteristics of TMT, firm position in the industry, specific characteristics of the firm and strategic patterns firm follow to achieve a temporary competitive advantage that is reflected in the change in firm performance and market share of the firm. Also, it can be used as a framework for further research in this area.

In order to investigate the extent to which certain firm behavior affects firm performance in the hypercompetitive conditions, different firm behaviors were defined and structured at first, which were then framed in the newly formed strategic taxonomy of strategy patterns. Daraboš (2014) define firm strategic patterns by two key variables that define and influence the behavior of companies in hypercompetition: (1) firm agility and (2) firm strategic innovation. Depending on the level of every individual variable, possible strategic patterns of specific firm behavior have been theoretically developed, what is the greatest scientific contribution of this doctoral theses.

Strategic patterns of firm can be defined as the perceived and identified conceptualizations based on a limited number of variables (firm agility and firm strategic innovation), where a clear delineation in the firm strategic behavior in the

Figure 1 .

TAXONOMY OF STRATEGY PATTERNS

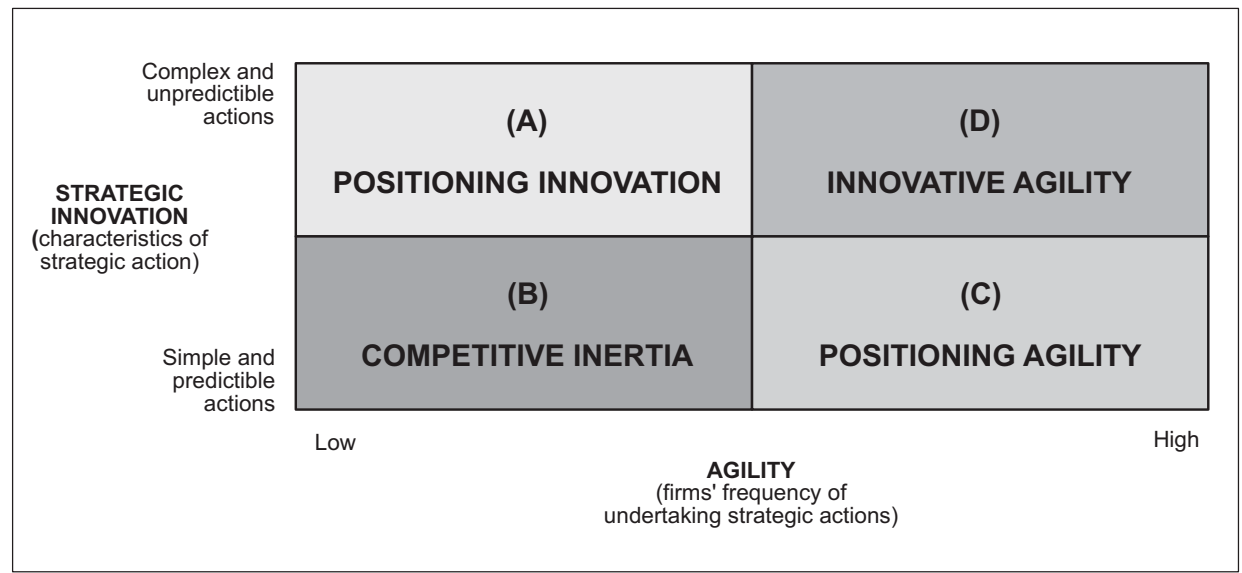


hypercompetitive conditions can be assumed (Daraboš, 2014). That means that it is possible to determine four groups of different strategies firms may follow, based on an alleged taxonomy and that are: (A) Positioning Innovation, (B) Competitive Inertia, (C) Positioning Agility, and (D) Innovative Agility (Fig.1) (Daraboš, 2014; Daraboš Longin, 2016). Such a classification was developed on dichotomous definitions and represents a starting basis for the research.

Therefore, framing a new taxonomy of strategic patterns of firms in hypercompetitive conditions is one of the scientific contributions of this research supported with an empirical research of behavior of Croatian firms according to the defined strategic patterns. When developing taxonomy of strategic patterns crucial was to establish and clarify the basic variables that differ given firm strategies.

After developing taxonomy of strategic patterns it was crucial to establish and clarify the main variables that differ firm given strategies. The first construct is firm agility. It is complex variable measured by the mean value of two defined variables that explain in detail and show strategic actions initiated by the firm. The first variable is the frequency of undertaking specific types of strategic actions. The specified variable measures undertaking certain types of strategic actions compared to strategic actions of direct competitors. The second variable is firm's reaction speed that shows firm recognition, reaction and anticipation of strategic opportunities and challenges in the environment in comparison with the speed of direct competitors. The assumption is the greater firm agility is, or higher frequency of undertaking actions, it is more likely the firm will succeed in achieving a temporary competitive advantage.

Firm strategic innovation represents the second construct defined by the mean value of complexity level and unpredictability of the actions initiated by the firm (the level of general firm innovation), as well as characteristics of actions itself initiated by the firm (the level of specific firm innovation). This construct is determined by the two key variables: general and specific strategic innovation. General strategic innovation shows innovation in the firm behavior in relation to its competitors in the industry through the introduction of new products / services, new production technologies, organizational solutions, as well as new management techniques. On the other hand, specific strategic innovation is explained through three auxiliary variables: the level of unpredictability, the level of complexity and the specific level of innovation. First mentioned, the level of unpredictability explains and describes the sequence of undertaking actions depending on the type of given action initiated by the firm in relation to direct competitors. The level of complexity (second auxiliary variable) describes the time it takes to prepare and initiate certain type of firm action in comparison to direct competitors. Consequently, actions are divided into simple or complex. Specific strategic innovation is the last auxiliary variable in strategic innovation model and it illus- 
trates the importance of undertaken action for the firm or industry in comparison with direct competitors.

Lower level of strategic innovation, i.e. undertaking simple and predictable strategic actions, on the one hand improves firm performance of the firm due to rapid implementation, and raises the possibility that competitors in this case can respond quickly enough and thus suppress the possibility of improving the firm performance of the firm that took action in the first place. On the other hand, complex and unpredictable actions will reduce the speed of implementation leading to the slower response of competitors because it is difficult to predict such actions, but also increases the possibility of improving firm performance (Ferrier, 2001). Therefore, it is important to observe the process of dynamic interaction between competitors through sequences of competitive actions and reactions of the rivals (Daraboš, 2014b).

For every individual key variable is constructed a special measure by examining the attitudes of TMT members by using a Likert measurement scale of five degrees of intensity, forming the level of agility, i.e. the level of strategic innovation for each firm in the sample.

In the model the agility level, as well as firm strategic innovation level, equal to 3.00 or greater is defined as a high level of the variable, while the mean values below 3.00 represent a low level of the variable. So, the values of 3.00 or above show significant activity in the market compared to direct competitors, as opposed to values below 3.00, which show lower activity in the market in comparison with the most important competitors. Considering that so far there was a very little research in this area, point of division in dichotomous terms "low-high" was made based on the presumption that the set measuring scale adequately match anticipated taxonomy.

High level of firm agility encompass two strategic patterns in the model: positioning agility and innovative agility. Both represent a frequent undertaking of actions by the firm, which means a constant presence and high level of competitive activity. Highly agile firms are those extremely competitive-oriented and those that enhance and improve their business in every way. If the firm is constantly better or a leader in the industry and leverages its strengths in order to further strengthen its reputation and increase market share, it will be able to overcome its competitors. The assumption is the higher level of firm agility is, i.e. higher frequency of undertaking action, it is more likely that the firm will succeed in achieving a temporary competitive advantage, in other words to improve its firm performance (Daraboš Longin, 2016).

On the other hand, higher level of firm strategic innovation encompasses two strategic patterns in the developed model: positioning innovation and innovative agility. These patterns are distinguished by firm agility, or by the frequency of 
undertaking actions. But still, both represent undertaking of complex and unpredictable actions by the firm, for which it is assumed that improve firm's firm performance, since it is more difficult for competitors to predict such an actions and thus, it is less likely competitors will response quickly enough (Daraboš Longin, 2016). Stated will result in an extended duration of competitive advantage for the firm that has come out of that strategic action.

Figure 2.

\section{PROPOSED MODEL OF RELATIONSHIP BETWEEN STRATEGY PATTERNS AND COMPETITIVE ADVANTAGE IN THE HYPERCOMPETITION}

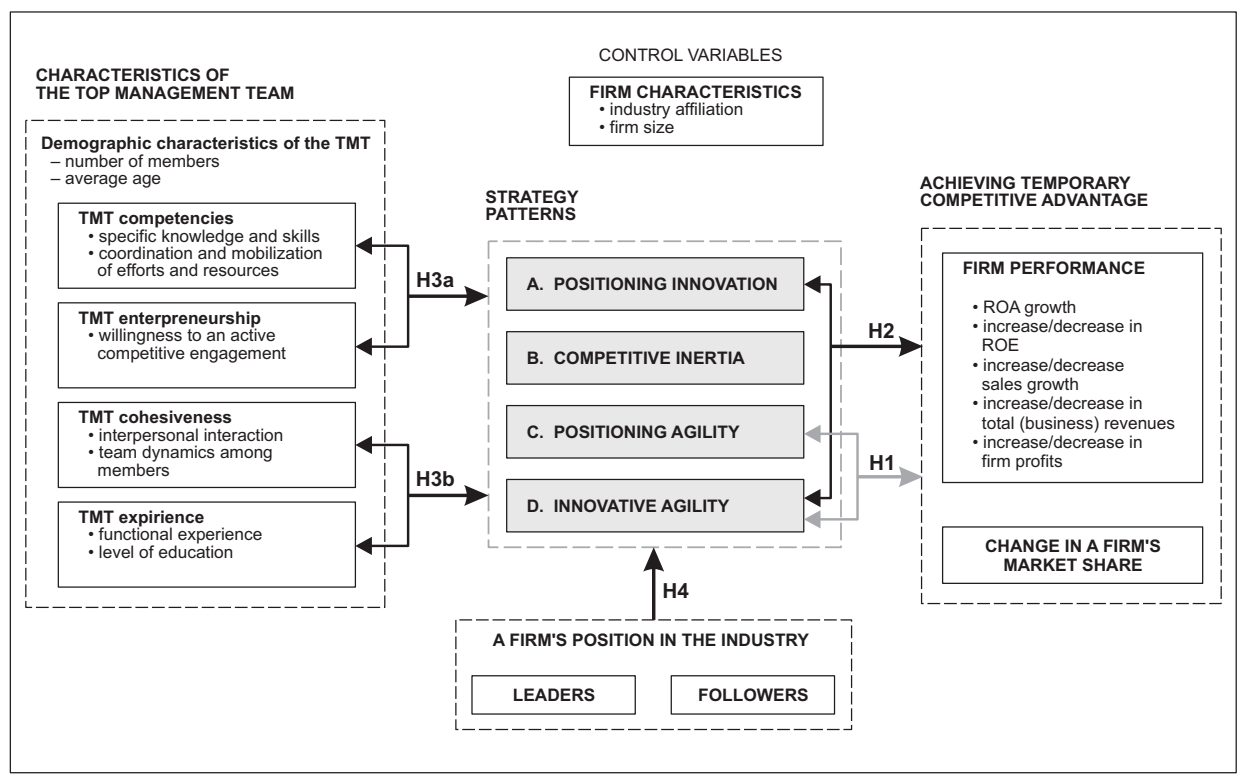

The hypotheses that will be tested in a scientific research within the framework of this paper in order to test the validity of the proposed model are:

H1. There is a positive relationship between the firm agility level and firm performance in the hypercompetitive industry.

H2. There is a positive relationship between firm strategic innovation level and firm performance in the hypercompetitive industry.

H3. TMT characteristics affect strategic pattern firm follows in the hypercompetitive industry. 
H3a. Competence and entrepreneurship of TMT affect strategic innovation in the hypercompetitive industry.

H3b. Cohesiveness and experience of TMT affect firm agility in the hypercompetitive industry.

H4. Leaders in the hypercompetitive industry follow strategy pattern "Innovative Agility".

\section{Empirical research}

The research was conducted on Croatian large and middle sized firms that are operating in the mobile telecommunications industry, cosmetics industry, printing industry and retail industry that were defined as hypercompetitive. For collecting primary data a poll survey was conducted, and 61 completed questionnaires were obtained from 61 different companies (out of totally 104 companies in selected industries), representing a $58.65 \%$ response rate. The above rate is acceptable given the sensitivity of the analyzed phenomena and the complexity of analysis (only one completed questionnaire from TMT member of every firm in sample - the firm strategy was analyzed).

Figure 3.

\section{SAMPLE DESCRIPTION - DISTRIBUTION OF FIRMS FROM SAMPLE DEPENDING ON THE INDUSTRY THEY OPERATE IN}

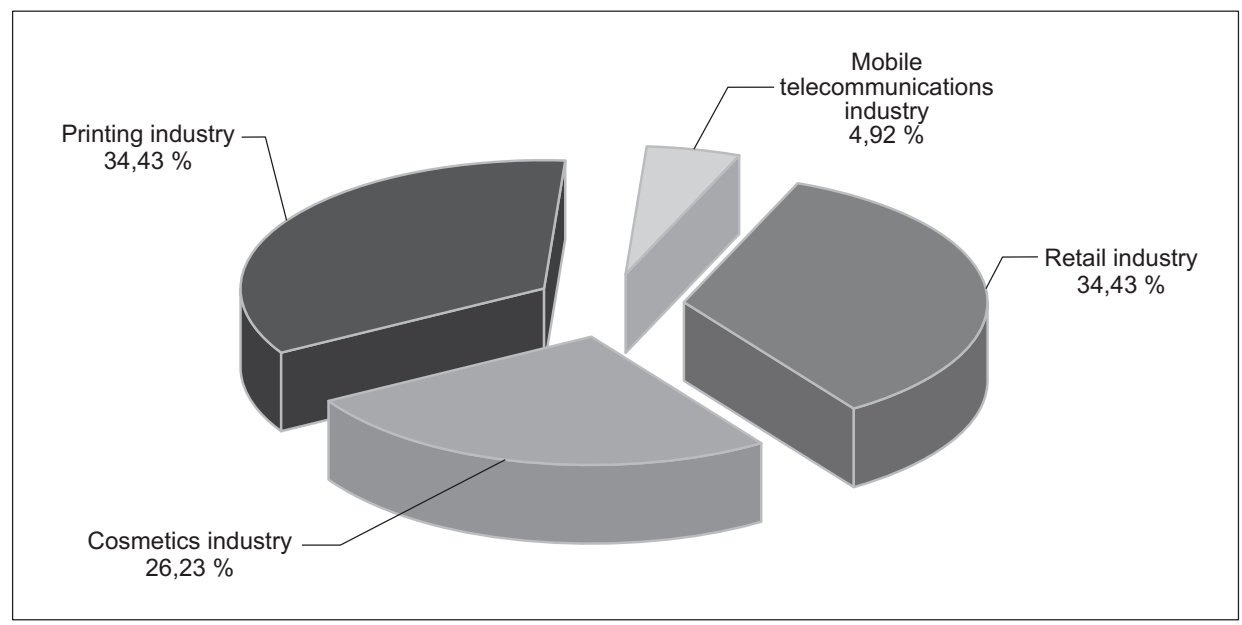


For the acceptance/rejection of set hypotheses the pattern of phenomena observation was not identical. The test of $\mathrm{H} 1, \mathrm{H} 2$ and $\mathrm{H} 3$ was conducted on the entire sample of 61 firms, while for $\mathrm{H} 4$ the phenomena was observed on the sample of 18 firms that are at the leading positions in their industry segments.

So, the first step needed for testing hypotheses was defining the level of each construct in each firm from the sample. This was necessary for distribution of firms into defined strategy patterns. According to the research results mean value of frequency of undertaking strategic actions (the level of agility) is 3.26, while the mean value of the level of strategic innovation for firms from the sample amounts 3.24 (Table 1).

Table 1:

MEAN VALUE OF KEY CONSTRUCTS IN STRATEGY PATTERN MODEL FOR FIRMS FROM SAMPLE

\begin{tabular}{llccc}
\hline \hline & $\mathbf{N}$ & $\begin{array}{c}\text { Minimum } \\
\text { value }\end{array}$ & $\begin{array}{c}\text { Maximum } \\
\text { value }\end{array}$ & $\begin{array}{c}\text { Mean } \\
\text { value }\end{array}$ \\
\hline $\begin{array}{l}\text { A1) Frequency of undertaking specific } \\
\text { types of strategic actions (A11-A16) }\end{array}$ & 61 & 1,50 & 5 & 3,12 \\
\hline $\begin{array}{l}\text { A2) Firms reaction speed (A21-A24) } \\
\text { FIRM AGILITY LEVEL }\end{array}$ & 61 & 1,50 & 5 & 3,41 \\
A1 + A2) & 61 & $\mathbf{1 , 5 0}$ & $\mathbf{4 , 9 2}$ & $\mathbf{3 , 2 6}$ \\
\hline $\begin{array}{l}\text { I1) General strategic innovation } \\
\text { I2) Specific strategic innovation }\end{array}$ & 61 & 1,75 & 5 & 3,30 \\
\hline $\begin{array}{l}\text { FIRM STRATEGIC INNOVATION } \\
\text { LEVEL (I= I1 + I2) }\end{array}$ & 61 & 1,40 & 5 & 3,18 \\
\hline
\end{tabular}

Furthermore, at Fig 4. and Fig 5., the level of agility and strategic innovation for all firms from the sample can be seen. 
Figure 4.

FIRMS FROM SAMPLE ACCORDING TO THE FIRM AGILITY LEVEL

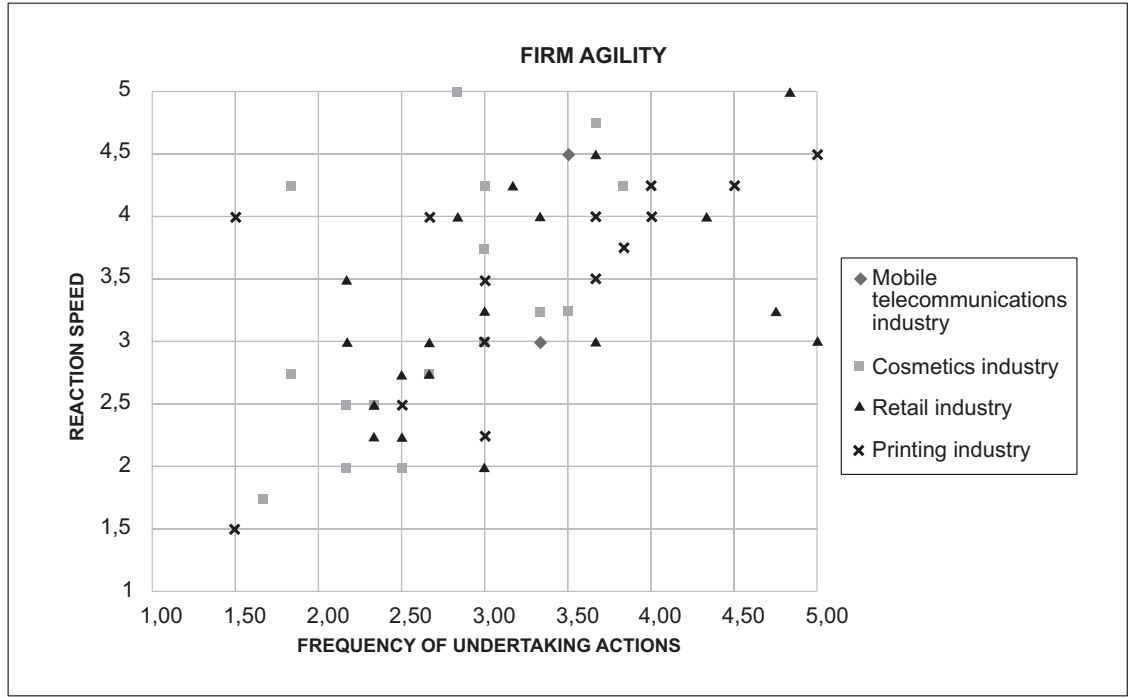

Figure 5.

FIRMS FROM SAMPLE ACCORDING TO THE FIRM STRATEGIC INNOVATION LEVEL

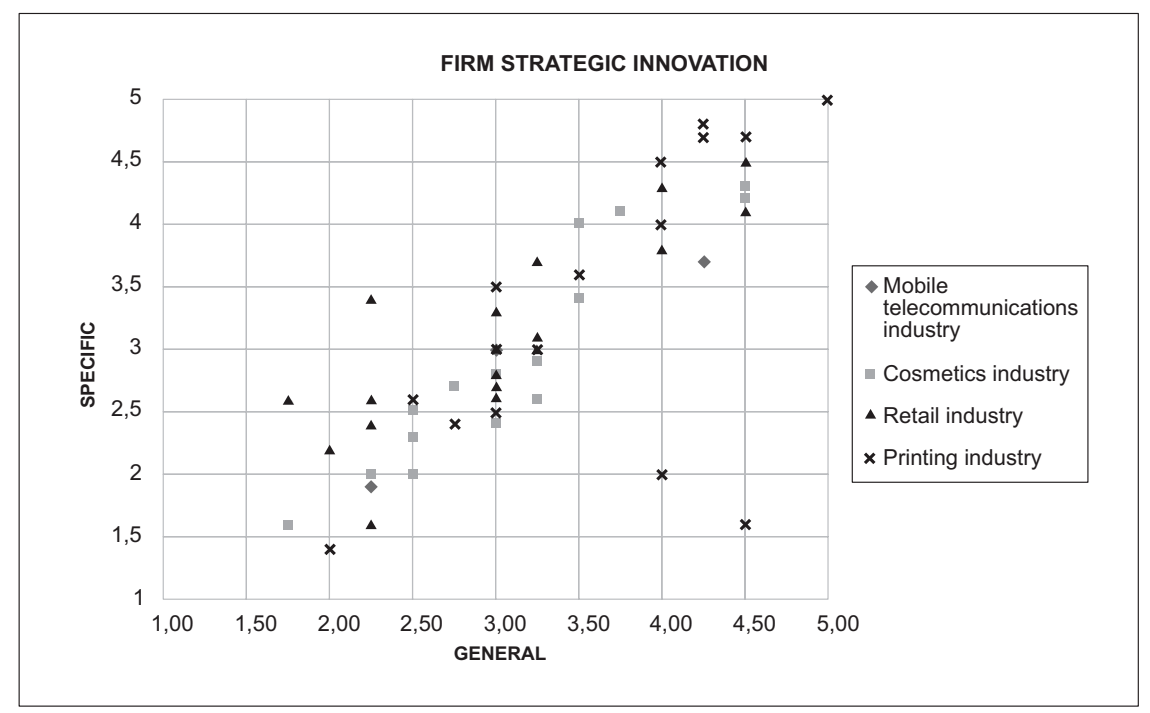


Furthermore, based on calculated values and obtained results, firms were divided into defined strategy patterns (Fig 6.).

Figure 6.

\section{DISTRIBUTION OF FIRMS FROM SAMPLE BASED ON DEFINED STRATEGY PATTERN AND INDUSTRY}

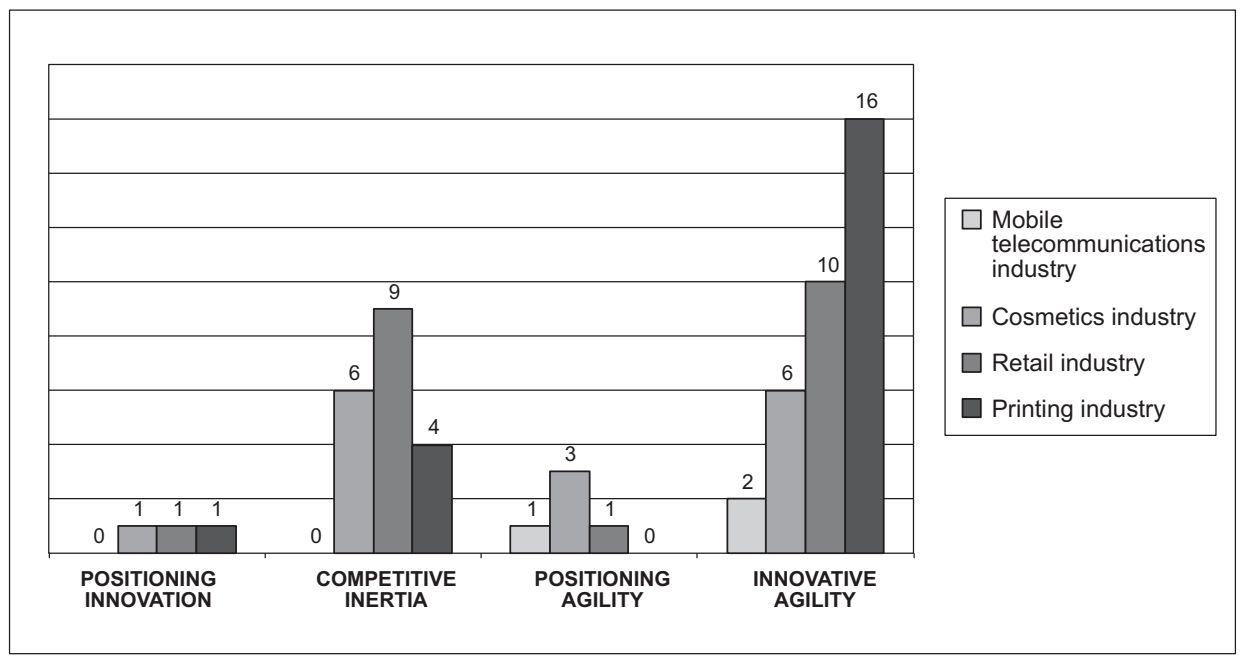

Based on calculated values strategic patterns for all firms have been identified. Strategic pattern of Positioning Innovation follow a total of three firms from the sample. Competitive Inertia is a strategic pattern in which 19 firms have been redistributed. Strategic pattern of Positioning Agility assumes a high level of agility and low level of firm strategic innovation with the five firms from the sample following this pattern. Firms that have extremely high level of competitive activity, i.e. a high level of agility and strategic innovation are arranged in the pattern of Innovative Agility with the total of 34 such firms from the sample.

At the beginning, focus was on the nature of the link between strategic patterns and firm performance. In order to investigate the extent to which a particular strategic pattern affect firm performance, an influence of two key variables on the firm performance in the strategic patterns construction will be examined. In particular, does the level of firm agility affect firm performance level, as well as the nature of given link (hypothesis H1). On the other hand, the link between the level of firm strategic innovation and firm performance will be also examined, as well as the nature of given link (hypothesis $\mathrm{H} 2$ ). 
In most of the researches this nature, as a measure of firm performance researchers usually use market performance indicators. Since Croatia, like most developing countries, is characterized by underdeveloped and illiquid capital market, it is believed that the use of capital market indicators cannot illustrate firm performance sufficiently well. Thus, different "non-market" firm performance indicators were used in this empirical research.

Financial data were collected for a period of three years, Firstly, data on total revenue and business revenues were used in the calculations of growth (or fall) of its value, more specifically, one-year, two-year and three-year growth/fall. Secondly, indicators that measure firm's profitability have also been calculated: increase/decrease in return on sales (ROS), increase/decrease in return to equity (ROE) and increase/decrease in return to assets (ROA).

Mentioned measures were used in order to calculate their value growth (or fall), in the same way as shown for the total and business revenue. One of the reasons why firm performance measures were used as a value of three-year growth is that in 2010 economic crisis and recession in the domestic economy reached the peak. So with the firm performance presented in this way it is believed that exogenous influences that are not a direct result of firm management will be mitigated, at least to some extent.

In the analysis, aside from the above mentioned financial indicators of the firm performance, the particular indicators of firm performance were collected through subjective assessment of the respondents (TMT members), for period of last three years. These particular indicators are: (1) firm position in the comparison to the largest direct competitor, (2) ROA growth in comparison to the ROA of the largest direct competitor, (3) increase/decrease in the firm revenue compared to the one of the largest direct competitor, (4) firm profits compared to the profits level of the largest diract competitor, and (5) number of new clients aquired in the comparison of new clients aquired by the largest competitor.

The first hypothesis assumes that there is a positive relationship between the level of agility and firm performance in hypercompetitive industry. Results of regression analysis show that the level of firm agility is statistically significant predictor of the likelihood the firm will achieve profitability growth. In this analysis, both, objective and subjective indicators of firm performance of the firm were observed for the period of last three years as well as their relation with the level of firm agility. The analysis confirmed a statistically significant correlation between both financial indicators of firm performance (the three-year growth of the total and business revenue) and firm agility level, at 10\% level of significance (sig=.069; $\operatorname{sig}=.090)$. 
Table 2:

\section{REGRESSION ANALYSIS OF INTERDEPENDENCE BETWEEN THE THREE-YEAR GROWTH OF THE TOTAL REVENUE AND FIRM AGILITY LEVEL}

\begin{tabular}{lrrrr} 
Term & Estimate & Std Error & t Ratio & Prob $>|t|$ \\
\hline Intercept & $-0,206336$ & 0,164286 & $-1,26$ & 0,2141 \\
\hline FIRM AGILITY LEVEL & 0,0905622 & 0,049005 & 1,85 & 0,0696
\end{tabular}

Table 3:

REGRESSION ANALYSIS OF INTERDEPENDENCE BETWEEN THE THREE-YEAR GROWTH OF THE BUSINESS REVENUE AND FIRM AGILITY LEVEL

\begin{tabular}{lrrrr} 
Term & Estimate & Std Error & t Ratio & Prob $>|\mathbf{t}|$ \\
\hline Intercept & $-0,163461$ & 0,151218 & $-1,08$ & 0,2841 \\
\hline FIRM AGILITY LEVEL & 0,0750919 & 0,045107 & 1,66 & 0,0903
\end{tabular}

Also, the results indicate a significant influence of the level of agility on the composite particular indicators of firm performance, at $1 \%$ level of significance $(\mathrm{sig}=.000)$. The above link is a positive direction, which in other words means that there is likelihood that firms with a higher level of agility will achieve a higher level of firm performance.

Table 4:

REGRESSION ANALYSIS OF INTERDEPENDENCE BETWEEN COMPOSITE PARTICULAR INDICATORS OF FIRM PERFORMANCE (WITH REGARD TO DIRECT COMPETITORS) AND FIRM AGILITY LEVEL

\begin{tabular}{lrrrr} 
Term & Estimate & Std Error & t Ratio & Prob $>|t|$ | \\
\hline Intercept & 1,1351293 & 0,373029 & 3,04 & $0,0035^{*}$ \\
\hline FIRM AGILITY LEVEL & 0,5513513 & 0,111271 & 4,96 & $<, 0001^{*}$
\end{tabular}

Regression analyses for second hypothesis confirm the assumption that there is an empirically provable positive relationship between the level of firm strategic 
innovation and firm performance in the hypercompetitive industry. In this analysis, financial and particular indicators of firm performance and their relationship with the firm strategic innovation were also observed. The results show a positive statistically significant relationship, at $10 \%$ level of significance, between some financial indicators of firm performance, the three-year growth in total revenues (sig=.092) and a three-year growth in business revenues (sig=.072) and the level of firm strategic innovation, but also for all particular indicators of performance, at $1 \%$ level of significance (sig=.000). In other words, firms with a higher level of strategic innovation have a higher level of firm performance.

Table 5:

REGRESSION ANALYSIS OF INTERDEPENDENCE BETWEEN THE THREE-YEAR GROWTH OF THE TOTAL REVENUE AND FIRM STRATEGIC INNOVATION LEVEL

\begin{tabular}{lrrrr} 
Term & Estimate & Std Error & t Ratio & Prob $>|t|$ \\
\hline Intercept & $-0,169404$ & 0,155603 & $-1,09$ & 0,2807 \\
\hline FIRM STRATEGIC & 0,079957 & 0,046672 & 1,71 & 0,0919
\end{tabular}

INNOVATION LEVEL

Table 6:

REGRESSION ANALYSIS OF INTERDEPENDENCE BETWEEN THE THREE-YEAR GROWTH OF THE BUSINESS REVENUE AND FIRM STRATEGIC INNOVATION LEVEL

\begin{tabular}{lcrrr} 
Term & Estimate & Std Error & t Ratio & Prob>|t|t] \\
\hline Intercept & $-0,17069$ & 0,142007 & $-1,20$ & 0,2342 \\
\hline $\begin{array}{l}\text { FIRM STRATEGIC } \\
\text { INNOVATION LEVEL }\end{array}$ & 0,077995 & 0,042594 & 1,83 & 0,0721 \\
\hline
\end{tabular}


Table 7:

\section{REGRESSION ANALYSIS OF INTERDEPENDENCE BETWEEN COMPOSITE PARTICULAR INDICATORS OF FIRM PERFORMANCE (WITH REGARD TO DIRECT COMPETITORS) AND FIRM STRATEGIC INNOVATION LEVEL}

\begin{tabular}{lrrrr} 
Term & Estimate & Std Error & t Ratio & Prob $>|t|$ \\
\hline Intercept & 1,0587211 & 0,334765 & 3,16 & $0,0025^{*}$ \\
\hline FIRM STRATEGIC & 0,5798785 & 0,100409 & 5,78 & $<, 0001^{*}$ \\
INNOVATION LEVEL & & & &
\end{tabular}

Studies conducted so far have investigated only the influence of demographic characteristics of TMT on firm competitive behavior and its firm performance. Therefore, the third hypothesis verified the direction and nature of the relationship between the characteristics of TMT and strategic pattern firm. In order to secure as precise analyses as possible, there are two auxiliary hypotheses, in which two pairs of TMT characteristics are separated (H3a - competence and entrepreneurship; H3B - cohesiveness and experience). Their influence on agility and firm strategic innovation was observed.

The results of regression analysis confirm that firms where TMT consists of members with a higher level of competence, i.e. with a higher level of entrepreneurial spirit, have significantly higher levels of strategic innovation $(\mathrm{H} 3 \mathrm{a})$, at $10 \%$ level of significance ( $\operatorname{sig}=.085$; sig=.080).

Table 8:

MULTIPLE REGRESSION ANALYSIS OF INTERDEPENDENCE BETWEEN FIRM STRATEGIC INNOVATION LEVEL AND TMT COMPETENCE LEVEL AND ENTREPRENEURSHIP LEVEL

\begin{tabular}{lrrrr} 
Term & Estimate & Std Error & t Ratio & Prob $>|\mathbf{t}|$ \\
\hline Intercept & 1,4287266 & 0,5715 & 2,50 & $0,0153^{*}$ \\
\hline TMT COMPETENCE LEVEL & 0,2027909 & 0,151103 & 1,34 & 0,0848 \\
\hline TMT ENTREPRENEURSHIP LEVEL & 0,2961934 & 0,183004 & 1,62 & 0,0800
\end{tabular}

Furthermore, the results show that there is a positive correlation, at 5\% level of significance (sig=.002) between the level of firm agility and the level of TMT cohesiveness, i.e. firms whose TMT consists of members who have a higher level of mutual cohesion, have a higher level of agility (H3B). However, the results do 
not show a statistically significant relationship between the level of firm agility and the level of TMT experience, and thus it can be concluded that the level of firm agility does not depend directly on the experience of TMT members.

Table 9:

\section{MULTIPLE REGRESSION ANALYSIS OF INTERDEPENDENCE BETWEEN FIRM AGILITY LEVEL AND TMT COHESIVENESS LEVEL AND EXPERIENCE LEVEL}

\begin{tabular}{lrrrr} 
Term & Estimate & Std Error & t Ratio & Prob $>|\mathbf{t}|$ \\
\hline Intercept & 1,4653041 & 0,738603 & 1,98 & 0,0520 \\
\hline TMT COHESIVENESS LEVEL & 0,4559506 & 0,144123 & 3,16 & $0,0025^{*}$ \\
\hline TMT EXPERIENCE LEVEL & $-0,005316$ & 0,10598 & $-0,05$ & 0,9602
\end{tabular}

Regardless of the intensity of hypercompetition, there is a rule that leaders should accelerate the development of new advantages with high competitive value, but low market value at a time when the industries are becoming more turbulent (Pacheco-de-Almeida, 2010). Therefore, fourth hypothesis assumes that the leaders will follow strategic pattern of innovative agility in order to preserve their own position in the hypercompetitive industries. Specified pattern assumes a high level of agility and a high level of strategic innovation, which indicates high activity of such firms in the market. Results of descriptive statistics show that leaders follow strategic pattern of innovative agility to a greater extent (61\%), while the proportion of using next strategic pattern (positional agility) amounts only $17 \%$, followed by the positioning innovation and competitive inertia with $11 \%$.

Table 10:

DISTRIBUTION OF FIRMS FROM SAMPLE INTO STRATEGY PATTERNS DEPENDING ON THEIR POSITION IN THE INDUSTRY

\begin{tabular}{|ccccc|}
\hline & $\begin{array}{c}\text { INNOVATIVE } \\
\text { AGILITY }\end{array}$ & $\begin{array}{c}\text { POSITIONING } \\
\text { AGILITY }\end{array}$ & $\begin{array}{c}\text { POSITIONING } \\
\text { INOVATION }\end{array}$ & $\begin{array}{c}\text { COMPETITIVE } \\
\text { INERTIA }\end{array}$ \\
\hline LEADERS & $\begin{array}{c}\mathbf{1 1} \\
(\mathbf{6 1 , 1 1} \%)\end{array}$ & $\begin{array}{c}3 \\
(16,67 \%)\end{array}$ & $\begin{array}{c}2 \\
(11,11 \%)\end{array}$ & $\begin{array}{c}2 \\
(11,11 \%)\end{array}$ \\
\hline FOLLOWERS & $\begin{array}{c}23 \\
(53,49 \%)\end{array}$ & $\begin{array}{c}2 \\
(4,65 \%)\end{array}$ & $\begin{array}{c}1 \\
(2,33 \%)\end{array}$ & $(39,53 \%)$ \\
\hline
\end{tabular}


Furthermore, levels of two key constructs have also been observed but separately for the firms that are leaders in their industries, or industry segments, and separately for the followers. Since strategy pattern "Innovative Agility" indicates high level of both key variables, we tried to determine the proportion of companies with high firm agility level and high firm strategic innovation level (equal or higher than 3,00) - Table 11 and 12 .

\section{Table 11:}

\section{FIRM PROPORTIONS DEPENDING ON THE AGILITY LEVEL AND THEIR POSITION IN THE INDUSTRY}

\begin{tabular}{ccc} 
& AGILITY LEVEL & \\
\hline & $\begin{array}{c}>=3 \\
\text { (high) }\end{array}$ & $\begin{array}{c}<3 \\
\text { (low) }\end{array}$ \\
\hline Leaders & 14 & 4 \\
& $(77,78 \%)$ & $(22,22 \%)$ \\
\hline Followers & 25 & 18 \\
\hline & $(58,14 \%)$ & $(41,86 \%)$ \\
\hline
\end{tabular}

Table 12:

\section{FIRM PROPORTIONS DEPENDING ON THE STRATEGIC INNOVATION LEVEL AND THEIR POSITION IN THE INDUSTRY}

\begin{tabular}{ccc}
\hline STRATEGIC INNOVATION LEVEL & \\
\hline Leaders & $\begin{array}{c}>=3 \\
\text { (high) }\end{array}$ & $\begin{array}{c}<3 \\
\text { (low) }\end{array}$ \\
\hline Followers & 13 & 5 \\
$(72,22 \%)$ & $(27,78 \%)$ \\
\hline & 24 & 19 \\
$(55,81 \%)$ & $(44,19 \%)$ \\
\hline
\end{tabular}

From the results it can be seen that even $77,78 \%$ of firms classified as the Leaders have high level of firm agility, and only $22 \%$ of them have low level of agility. Additionally, comparing that proportion to the proportion of the Followers, there is once more superior result in favor of the Leaders - 78\% versus 58\%. Likewise, the descriptive statistics results show that proportion of the Leaders that 
have high level of strategic innovation (72\%) is also higher than proportion of the Followers with high level of strategic innovation (56\%).

Finally, it can be concluded that the leaders in the hypercompetitive industry follow strategic pattern "Innovative Agility" significantly more in comparison with other defined patterns - 44,44\% more leaders from the sample ensuing given pattern.

\section{Conclusion}

The results show how the level of the key variables firm agility and firm strategic innovation represent a significant predictor of the likelihood that a company that operates in the hypercompetitive conditions will experience superior profitability, i.e. achieve the temporary competitive advantage. In other words, these variables are the crucial characteristics of the behavior of firms in the hypercompetitive industries if the companies are to survive and retain the competitive advantage. This paper contributes to the field literature by providing new insights into the understanding of the strategic behavior of firms in dynamic environments especially through development of new taxonomy of strategy patterns.

Furthermore, the results verified the direction and nature of the relationship between the characteristics of TMT and strategic pattern firm follows. This showed that entrepreneurship, cohesiveness and competences are TMT characteristics that increase the firm agility as well as the firm strategic innovation level, while TMT experience is not directly related to the mentioned firm behavior. Additionally, the most preferable strategic behavior for success in hypercompetition include the high level of both strategic agility and strategic innovation and the results confirmed the fact that most of the leaders in industries pursue the strategic pattern "innovative agility" that involve that firm characteristics.

In conclusion, the research results provide empirical evidence that can help in understanding the determinants of corporate behavior in hypercompetition. Identifying important factors, processes and dynamics that influence the achievement of competitive advantages in hypercompetition as well as establishing links between the specific firm behavior and changes in the firm performance, are of great importance when identifying ways how Croatian firms could raise their competitiveness in such specific conditions. 


\section{REFERENCES}

Barnett, W. P. (1997) The Dynamics of Competitive Intensity, Administrative Science Quarterly, 42 (1), pp. 128-160

Baron, R. A. (2007) Behavioral and Cognitive Factors in Entrepreneurship: Entrepreneurs as the Active Element in New Venture Creation, Strategic Entrepreneurship Journal, 1 (1-2), pp. 167-182

Bazerman, M. H. and Schoorman, F. D. (1983) A Limited Rationality Model of Interlocking Directorates, Academy of Management Review, 8 (2), pp. 206-217

Bruining, H. and Wright, M. (2002) Entrepreneurial Orientation in Management BuyOuts and the Contribution of Venture Capital, Venture Capital, 4 (2), pp. 147-168

Chen, M. J. (1996) Competitor Analysis and Interfirm Rivalry: Toward a Theoretical Integration, Academy of Management Review, 21 (1), pp. 100-134

Chen, M. J. i MacMillan, I. C. (1992) Nonresponse and Delayed Response to Competitive Moves: The Roles of Competitor Dependence and Action Irreversibility, Academy of Management Journal, 35 (3), pp. 539-570

Chen, M. J., Smith, K. G. i Grimm, C. M. (1992) Action Characteristics as Predictors of Competitive Responses, Management Science, 38 (3), pp. 439-455

Chen, M. J., Lin, H. C. and Michel, J. G. (2010) Navigating in a Hypercompetitive Environment: The Roles of Action Aggressiveness and TMT Integration, Strategic Management Journal, 31 (13), pp. 1410-1430

Chen, M. J. (2009) Competitive Dynamics Research: An Insider's Odyssey, Asia Pacific Journal of Management, 26 (1), pp. 5-25

Chen, M. J. and Hambrick, D. C. (1995) Speed, Stealth, and Selective Attack: How Small Firms Differ from Large Firms in Competitive Behavior, Academy of Management Journal, 38 (2), pp. 453-482

Darabos, M. (2014) Strategic patterns and competitive advantage in hypercompetition. $\mathrm{PhD}$ Dissertation. Faculty of Economics and Business Zagreb. (in Croatian)

Darabos, M. (2014b) Top Management Team Cohesiveness and Firm Agility, in the book „Rethinking Corporate Governance“ (Tipurić, D., Vrdoljak Raguž, I. i Podrug, N., ur.), Harlow, England: Pearson Education, pp. 154-165

Darabos, M., Prester, J. and Tipurić, D. (2015) Entrepreneurial Spirit of Top Management Team: Is there any Influence on Strategic Innovation?, in the book „Dynamics of organizational change: Beyond identity and reputation“ (Tipurić, D., Vrdoljak Raguž, I. i Daraboš, M., ur.), Harlow: Pearson Education Limited, pp. 35-46

Darabos, M. (2015) Evolution of competitive advantage: In search for success in hypercompetition. Zagreb: Naklada Ljevak. (in Croatian)

Darabos Longin, M. (2016) Firm strategic behaviour in hypercompetition: Is there a link with sustainable competitive advantage?, International Journal of Arts and Sciences, 9 (2), str. 667-675. 
D’Aveni, R. A., Dagnino, G. B. and Smith, K. G. (2010) The Age of Temporary Advantage?, Strategic Management Journal, 31 (13), pp. 1371-1385

D’Aveni, R. A. (1994) Hypercompetition: Managing the Dynamics of Strategic Manouvering. New York: Free Press.

Davis, D., Morris, M. and Allen, J. (1991) Perceived Environmental Turbulence and its Effects on Selected Entrepreneurship, Marketing and Organizational Characteristics, Journal of the Academy of Marketing Science, 19 (1), pp. 43-51

Ferrier, W. J. (2001) Navigating the Competitive Landscape: The Drivers and Consequences of Competitive Aggressiveness, Academy of Management Journal, 44 (4), pp. 858-877

Ferrier, W. J., Smith, K. G. and Grimm, C. M. (1999) The Role of Competitive Action in Market Share Erosion and Industry, Academy of Management Journal, 42 (4), pp. 372-388

Goodstein, R. C. and Escalas, J. E. (1994) UPC Scanner Pricing Accuracy: A Review of Research and Managerial Implications, Pricing Strategy \& Practice: An International Journal, 2 (1), pp. 4-10

Grimm, C. M., Lee, H. and Smith, K. G. (2006) Strategy as Action: Competitive Dynamics and Competitive Advantage. New York: Oxford University Press.

Hambrick, D. C., Cho, T. S. and Chen, M. J. (1996) The Influence of Top Management Team Heterogeneity on Firms' Competitive Moves, Administrative Science Quarterly, 41 (4), pp. 659-684

McNamara, G., Vaaler, P. and Devers, C. (2003) Same as it Ever Was: The Search for Evidence of Increasing Hypercompetition, Strategic Management Journal, 24 (3), pp. 261-278

Morris, M. H. and Sexton, D. L. (1996) The Concept of Entrepreneurial Intensity: Implications for Company Performance, Journal of Business Research, 36 (1), pp. $5-13$

Ozgen, E. and Baron, R. A. (2007) Social Sources of Information in Opportunity Recognition: Effects of Mentors, Industry Networks, and Professional Forums, Journal of Business Venturing, 22 (2), pp. 174-192

Pacheco-de-Almeida, G. (2010) Erosion, Time Compression, and Self-displacement of Leaders in Hypercompetitive Environments, Strategic Management Journal, 31 (13), pp. 1498-1526

Sirmon, D. G. et al. (2010) The Dynamic Interplay of Capability Strenghts and Weaknesses: Investigating the Bases of Temporary Competitive Advantage, Strategic Management Journal, 31 (13), pp. 1386-1409

Smith, K. G. et al. (1991) Organizational Information Processing, Competitive Responses, and Performance in the U.S. Domestic Airline Industry, Academy of Management Journal, 34 (1), pp. 60-85

Smith, K. G. et. al. (1994) Top Management Team Demography and Process: The Role of Social Integration and Communication, Administrative Science Quarterly, 93 (3), pp. $412-438$ 
Smith, K. G., Ferrier, W. J. and Grimm, C. M. (2001) King of the Hill: Dethroning the Industry Leader, The Academy of Management Executive, 15 (2), pp. 59-70.

Summers, I., Coffelt, T. and Horton, R. (1988) Work Group Cohesion, Psychological Reports, 63 (2), pp. 627-636

Wiggins, R. R. and Ruefli, T. W. (2002) Sustained Competitive Advantage: Temporal Dynamics and the Incidence and Persistence of Superior Economic Performance, Organization Science, 13 (1), pp. 82-105

Wiggins, R. R. and Ruefli, T. W. (2005) Schumpeter's Ghost: Is Hypercompetition Making the Best of Times Shorter?, Strategic Management Journal, 26 (10), pp. 887-911

Young, G., Smith, K. G. and Grimm, C. M. (1996) "Austrian“ and Industrial Organization Perspectives on Firm-level Competitive Activity and Performance, Organization Science, 7 (3), pp. 243-254

\section{STRATEŠKI OBRASCI I KONKURENTSKA PREDNOST U HIPERKONKURENCIJI}

\section{Sažetak}

Agresivnost u poduzimanju akcija smatra se reakcijom poduzeća na fenomen privremene prednosti. Poduzeća koja brzo reagiraju na zahtjeve tržišta jačaju svoju tržišnu snagu i stvaraju prednosti, ali ona koja mogu to učiniti još brže generiraju još veću tržišnu snagu i prednost nad svojim konkurentima. Međutim, ne postoji jamstvo da će danas postignuta konkurentska prednost ostati dugoročno nepromijenjena. Naglasak je na spremnosti poduzimanja akcija, točnije, mjeri u kojoj je poduzeće spremno sudjelovati s konkurentima te brzo reagirati u uključivanju i sudjelovanju na tržištu. Dinamika vrhovnog menadžmenta vrlo je važna komponenta sposobnosti konkurentskog ponašanja poduzeća. Tim vrhovnog menadžmenta je glavni element koji koordinira i mobilizira organizacijske resurse i napore za agresivno natjecateljsko angažiranje poduzeća. Pretpostavka agresivnijeg ponašanja na tržištu i suradnje s konkurentima je integracija vrhovnog menadžmenta koja prvenstveno ovisi o kompatibilnim osobinama i komunikacijskim vještinama članova. S posebnim naglaskom na timove vrhovnog menadžmenta, ovaj rad istražuje u kojoj se mjeri određeno strateško ponašanje poduzeća u hiperkonkurentskoj industriji može povezati sa stjecanjem privremene konkurentske prednosti, mjereno kroz poboljšanja poslovne uspješnosti poduzeća. Središnji cilj ovog istraživanja je teoretski i empirijski definirati i proučiti strateško ponašanje poduzeća u hiperkonkurenciji kroz definiranje nove taksonomije strateških obrazaca, tj. specifično strateško ponašanje poduzeća koje pruža i povećava vjerojatnost ostvarivanja konkurentske prednosti u hiperkonkurentnim industrijama. Važan doprinos ovog istraživanja također se odražava u razvoju modela koji analizira utjecaj specifičnih osobina tima vrhovnog menadžmenta (TMT) na obrasce koje poduzeće koristi, kao i odnos između tržišne pozicije poduzeća na specifično strateško ponašanje.

Ključne riječi: agresivnost, konkurentska prednost, poslovna uspješnost poduzeća, hiperkonkurencija, tim vrhovnog menadžmenta (TMT), strateški obrazac poduzeća 